\title{
原発性肺癌患者に拈ける各種腫瘍マーカーの臨床的検討
}

\author{
島袋 全哲 \\ 日本医科大学臨床病理学教室（主任：车谷久暢教授）
}

\section{A clinical evaluation of the versality of various tumor markers in diagnosing the primary carcinoma of the lung}

\author{
Zentetsu Shimabukuro \\ Department of Clinical Pathology, Nippon Medical School
}

In this study, the author has evaluated the diagnostic versatility of the neuron specific enolase (NSE), carcinoembryonic antigen (CEA), tissue polypeptide antigen (TPA), and serum antigens (KA 32, KA 93) which are detected by anti-human lung carcinoma monoclonal antibodies (KM 32, KM 93) in patients before initiating any treatment. The positive rates of the serum NSE, CEA, TPA, KA 32 and KA 93 in all patients suffering from lung carcinoma were $31.4 \%(32 / 102), 52.8 \%$ (56/106), $63.3 \%(62 / 98), 52 \%(13 / 25)$ and $20 \%$ $(24 / 120)$ respectively. Serum NSE was positive in $80.8 \%(21 / 26)$ of patients suffering from small cell type lung carcinoma (SCLC) and the mean value $(32.7 \pm 25.4 \mathrm{ng} / \mathrm{m} l)$ was significantly higher than those of other varieties of lung carcinoma. The positive rate of serum CEA in adenocarcinoma (70.2\%) was significantly higher than those of squamous cell carcinoma (22.2\%). There was no significant statistical difference in positive rates of TPA in various histological types of lung carcinoma. The NSE and CEA were $44.0 \%(22 / 50)$ and $70.6 \%(36 / 51)$ in the stage IV disease and they appeared to reflect the progress and extent of the disease. The TPA tended to show a positive rate even at the initial stage of the disease, but, it was noteworthy that this disclosed a relatively high false positive rate of $54.2 \%$ (13/24). Moreover, determination of the serum NSE was performed chronologically. A lowered serum NSE value was confirmed in all cases which responded to the therapeutic attempts and unchanged values or even elevated values were noted in cases which showed no favourable response or rapid progression of the disease.

It was also noteworthy that the serum NSE elevation was found 2-6 weeks prior to the clinical confirmation of the recurrence of the tumor in three patients suffering from SCLC. Based on these observations, it is suggested that the serum NSE may serve as a versatile tumor marker in monitoring the stage of disease, effectiveness of the therapeutic attempts and prediction of the possibility of the recurrence in SCLC. However, in view of the fact that some of the cases that obviously demonstrated clinical evidence of tumor recurrence failed to show elevation of the NSE, caution should be exercised in evaluating the alteration of the positive rates. The monoclonal antibody that works against human lung squamous cell carcinoma (KM 32) and antibody that works against human lung adenocarcinoma (KM 93) were isolated and purified. The sandwich ELISA method, using these antibodies for diagnosing lung carcinoma has been attempted.

The positive rate of the serum KA 32 was $50 \%$ (4/8) in squamous cell carcinoma, $31.3 \%$ (5/16) in nonmalignant respiratory disease and $11.1 \%(2 / 18)$ in normal condition. The positive rate of the serum KA 93 was detected as $39.7 \%(23 / 58)$ in adenocarcinoma of the lung, and $4.8 \%(1 / 21)$ in small cell carcinoma of the lung. However, no positive rate was confirmed in other sub-types of lung carcinoma, non-malignant respiratory disease or in normal subjects. KA 32 and KA 93 tended to be positive with the progression of the clinical course, but they failed to show any close interrelationship with the positive rate of the serum CEA. Furthermore, the results may indicate a possibility that KA 32 and KA 93 could serve as versatile newly developed tumor markers for serum diagnosis of lung carcinoma.

Key words: lung cancer, tumor marker, neuron specific enolase, diagnosis and monitoring treatment, monoclonal antibodies 


\section{緒 言}

最近, 悪性腫瘍の診断, 治療効果の判定, 再発, 増 悪の予知, 予後の判定などを把握する指標として, 多 くの腫埸マーカーが臨床に応用されるとともに，さら に適格なマーカーを追求する研究が展開されている.

現在, 比較的臟器特異性の高い腫瘍マーカーとして, 肝癌に対する $\alpha$-fetoprotein (AFP), 膵癌, 胆管癌に 対する carbohydrate antigen 19-9 (CA 19-9), 大腸癌 に対する carcinoembryonic antigen (CEA), 䋐毛組 織に由来する腫瘍に対する human chorionic gonadotropin (HCG)などがあげられ，それぞれの腫 瘍の診断, 経過に伴ら病態把握の指標として, 臨床的 に広く用いられている。

肺癌に関しては, 組織型, 病期, 治療効果, 再発, 予後と関連して CEA が特に広く検討されている。し かしその陽性率は 40６0\%にとどまり，臨床的意義は 限られている。

一方, 2-phosphoglyceric acid $と 2$-phosphopyruvic acidの代謝過程を触媒する, 解糖系酵素 enolase の isoenzyme である neuron specific enolase (NSE) が, グルカゴノーマ, インスリノーマ, 神経芽細胞腫, 褐 色細胞腫, 甲状腺䯣様癌なと, 神経内分泌細胞に由来 する腫煌で高值を示すことが報告されている では, 同じ神経内分泌細胞由来と考えられる肺小細胞癌 についても，高い陽性率を示すことで注目されている1).

殊に肺小細胞癌は, きわめて早い増殖, 進展, 転移 をさたすことで, 他の組織型の肺癌に比較して悪性度 の高い腫煌として知られている。しかし, 放射線㞠法, 各種の抗癌剤に対して高い感受性を示し，これらの治 療によって完全寛解 (complete response) となった症 例には，明らかな延命が認められている。したがって， 完全寬解をきたした症例を，さらに治癒に至らしめる ためには, 早期に再発, 増悪を予知し, 適切な治療を 早期に開始することが肝要でらる.

こうした観点から, 著者は原発性肺癌患者を対象に, 血清 NSE, CEA, tissue polypeptide antigen (TPA) を測定し，腫場マーカーとしての意義を検討するとと るに, 殊に肺小細胞癌に高い陽性率を示す血清 NSE の臨床的意義と，その有用性について検討を加えた。 さらに，新たに八イブリドーマ技法で得られた，肺癌 に高い特異性を有するモノクローナル抗体である, KM 32, KM 93 について，その臨床的有用性を検討 した.

\section{研究対象および方法}

血清 NSE の測定対象は，未治療の原発性肺癌患者 102 例で，その内訳は男性 82 例，女性 20 例，平均年齢 63.8 歳（37 88 歳）である. 健常者 20 名（尿，血液 検査等で異常を認めなかった者）の内訳は男性 10 名, 女性 10 名, 平均年齢 50.3 歳 (35 62 歳) である. 非 腫瘍性疾患患者 50 例（呼吸器疾患 8 例, 胃漬瘍 11 例, 肝炎 12 例, 胆道疾患 4 例，心疾患 4 例，腸疾患 5 例， その他 6 例）の内訳は男性 35 例，女性 15 例，平均年 齢 61.3 歳 (47 76 歳) である.

原発性肺癌患者を日本肺癌学会病期分類にしたがっ て分類すると，I 期 2 例，II期 10 例，III期 40 例，IV 期 50 例である. 組織型別では, 腺癌 44 例, 扁平上皮 癌 24 例, 小細胞癌 26 例, 大細胞癌 8 例である.

血清 CEA の測定対象は, 未治療の原発性肺癌患者 106 例で, その内訳は男性 86 例, 女性 20 例, 平均年龄 64.1 歳(37-88 歳)である. 病期分類では, I 期 2 例, II 期 10 例, III期 43 例, IV期 51 例である. 組織型別で は, 腺癌 47 例, 扁平上皮癌 27 例, 小細胞癌 24 例, 大 細胞癌 8 例である。

血清 TPAの測定対象は, 未治療の原発性肺癌患者 98 例で, その内訳は男性 90 例, 女性 8 例, 平均年齢 62.3 歳（37 - 85 歳）である. 健常者 50 名の内訳は, 男性 25 名, 女性 25 名, 平均年齢 52.4 歳 (41 66 歳) である. 非腫湯性疾患患者 24 例(呼吸器疾患 9 例, 肝 炎 10 例, 肝硬変 5 例) の内訳性, 男性 17 例, 女性 7 例, 平均年齢 52.8 歳 ( $32 \sim 79$ 歳) である.

肺癌患者の病期分類では, I 期 2 例, II 期 10 例, III 期 42 例, IV期 44 例で, 組織型別では, 腺癌 43 例, 扁 平上皮癌 25 例, 小細胞癌 23 例, 大細胞癌 7 例である.

なお，同一検体で血清 NSE と CEA を測定した肺癌 症例は 95 例，血清 NSE と TPA を測定した肺癌症例 は90 例で，血清 NSE，CEA，TPAの三者を測定しえ た肺癌症例は 90 例である。

ヒ卜肺扁平上皮癌に対するモノクローナル抗体 KM 32 によって検出される血清中の抗原 KA 32 の測 定対象は, 未治療の原発性肺癌患者 35 例で, その内訳 は男性 26 例, 女性 9 例, 平均年齢 63.2 歳( $37 \sim 85$ 歳) である、健常者 18 名の内訳は男性 10 名, 女性 8 名, 平均年齿 60.3 歳 (38 -75 歳)である. 非腫瑒性呼吸器 疾患患者 16 例の内訳は, 男性 11 例, 女性 5 例, 平均 年路 64 歳（46 74 歳）である.

肺癌の病期分類では， I 期 2 例，II 期 2 例，III期 15 
例，IV期 16 例で，組織型別では，腺癌 17 例，扁平上 皮癌 8 例, 小細胞癌 6 例, 大細胞癌 4 例である.

ヒ卜肺腺癌に対するモノクローナル抗体 KM 93 に よって検出される血清中の抗原 KA 93 の測定対象は, 未治療の原発性肺癌患者 120 例で，その内訳は男性 93 例，女性 27 例，平均年齢 65.3 歳 (35 85 歳) である。 健常者 26 名の内訳は, 男性 16 名, 女性 10 名, 平均年. 齢 60.4 歳 ( 40 ７2 歳)である. 非腫場性呼吸器疾患患 者 16 例の内訳は, 男性 11 例, 女性 5 例, 平均年齢 64 藏（46〜74 歳）である。

肺癌の病期分類では，I期 3 例，III期 10 例，III期 50 例, IV期 57 例で, 組織型別では, 腺癌 58 例, 扁平上 皮癌 32 例，小細胞癌 21 例，大細胞癌 9 例である.

被検血清は, 1985 年 1 月〜同年 8 月までに当院拉よ び関連病院に入院した患者から得た，採血後，すみや かに遠心分離後, $-70^{\circ} \mathrm{C}$ にて凍結保存した。

（1）血清 NSE の測定法

栄研イムノヶミカル研究所で開発された, 2 抗体法に よる radioimmunoassay (RIA) キットで測定した，精 製扣よび標準 NSEは，ウシ脳より分離したものであ り，抗 NSE ウサギ血清(第 1 抗体)は，精製ウシ NSE を抗原としてウサギを免疫して得たものである.

（2）血清 CEA の測定法

「第一」CEA キットを用いた。固相一次抗体と標識 二次抗体を用いる two site immunoradiometric assay 法にて測定した。

（3）血清 TPA の測定法

第一ラジオアイソトープ研究所の 2 抗体法による radioimmunoassay（RIA）キットで測定した。TPA 抗血清は, Hela 細胞をウマに感作して得た抗血清で ある。

(4) 抗ヒ卜肺癌モノクローナル抗体 KM 32, KM 93 に上る血清中の抗原 KA 32,KA 93 の検出

協和発酵東京研究所（町田市旭町 3-6-6) の好田 肇博士らによって開発された，七ト肺扁平上皮癌細胞 の膜成分に対するモノクローナル抗体 KM 32, お上び ヒト肺腺癌練胞膜成分に対するモノクローナル抗体 KM 93 を用いた ${ }^{3,4)}$.

1) サンドウイッチELISA 法

KM 32 は，血液型関連桾鎖抗原のうち， A 型関連糖 鎖を認識すると思われたので，その欠点を解決する目 的で，ウサギを用いて作製した，ヒトA 型赤血球で吸 収した抗七卜肺扁平上皮癌株化細胞 PC-10 細胞抗体 (IgG 分画)をEIA 用プレートのコーティングに用い
た。コーティングした 96 穴 EIA 用プレートの各穴に 10 倍希䣋した被検血清 $50 \mu l$ を加克， 1 晚 $4{ }^{\circ} \mathrm{C}$ で反応 させた。洗浄後, $\mathrm{KM} 32(10 \mu \mathrm{g} / \mathrm{m} l) 50 \mu l$ を加光， 2 〜 3 時間反応させ，ペルオキシダーゼ標識抗マウス免 度グロブリン抗体溶液 $50 \mu l$ を加克, 反応後, 酵素活性 を測定した．KM 32 にって検出される血清中の抗 原：KA 32 量は，ゲルクロマトグラフィーで患者血清 から精製した標準抗原溶液を用いて下記の式より求 めた。

$\mathrm{KA} 32(\mathrm{U} / \mathrm{m} l)=$

$$
\frac{\text { OD test }- \text { OD blank }}{\text { OD standard }- \text { OD blank }} \times 100
$$

KM 93 によって検出される血中抗原；KA 93 の検 出も，KM 93 拉よびビオチン化 KM 93 を用いたサン ドゥイッチ ELISA 法で行った。

\section{結 果}

\section{1. 肺癌の組織型と各種マーカー}

健常者 20 名について血清 NSE を測定した結果，乙 の平均値は $5.2 \pm 0.9 \mathrm{ng} / \mathrm{m} l$ (range 4.2 6.9) であっ た. Fig. 1 に示すごとく, $10 \mathrm{ng} / \mathrm{m} l$ を cut off 值とす ると，健常者では $10 \mathrm{ng} / \mathrm{m} l$ 以上を示す陽性例は認め られなかった。

非腫場性疾患患者 50 例に扔ける血清 NSE の平均 值は $4.2 \pm 1.0 \mathrm{ng} / \mathrm{ml}$ (range 2.1 6.9) で，健常者之 同様に陽性例は認められなかった。

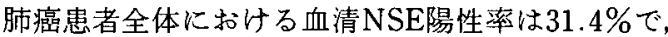
これを組織型別にみると，小細胞癌に打いて $80.8 \%$ と高 い陽性率を示し，その平均值も $32.7 \pm 25.4 \mathrm{ng} / \mathrm{m} l$ で, 他の組織型の平均値との比較では, 腺癌 $(6.3 \pm 3.0 \mathrm{ng} /$ $\mathrm{m} l)$, 扁平上皮癌 $(7.8 \pm 6.9 \mathrm{ng} / \mathrm{m} l)$ とは $\mathrm{p}<0.001(\mathrm{t}$ 検定) で，また大細胞癌 $(10.1 \pm 5.0 \mathrm{ng} / \mathrm{m} l)$ 之は $\mathrm{p}<$ 0.02 ( $\mathrm{t}$ 検定）と有意に高値を示した（Fig. 1).

肺癌患者全体の血清 CEA 陽性率は $52.8 \% て ゙ ，$ 組織 型別検討では，腺澏は $70.2 \%$ 示し，扁平上皮癌の陽 性率 $22.2 \%$ とは $\chi^{2}$ 険定で $\mathrm{p}<0.01$ と有意差を認め た。しかし，平均値の検討では，いずれの組織型間で あ有意差は認めなかった（Fig. 2).

健常者 50 名について血清 TPA を測定した結果，そ の平均值は 86.9土18.4 U/l (range 48.2 117.8) で あった。平均值 $\pm 2 \mathrm{SD}$ の上限から, cut off 值を $125 \mathrm{U} /$ しとすると，健常者では陽性例は認められなかった。

非腫瘍性疾患患者 24 例に打ける血清 TPA の平均 值は $157.0 \pm 96.1 \mathrm{U} / l$ （range 60４41）を示し，その 


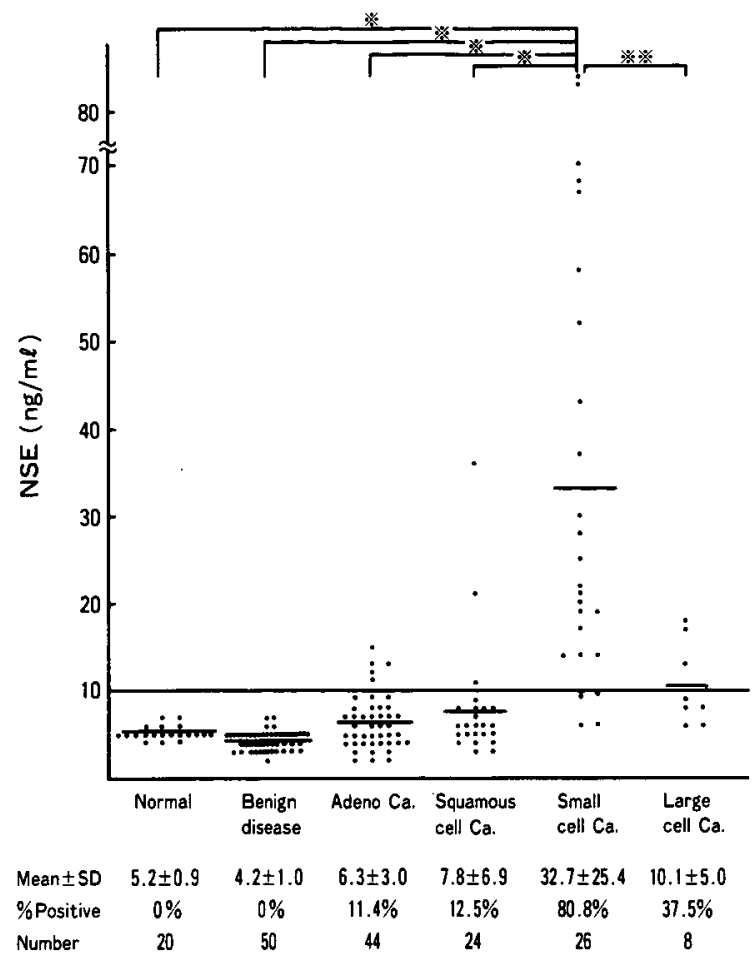

Fig. 1 Ranges of serum NSE levels in controls and patients with benign disease or carcinoma of the lung

NSE: neuron specific enolase, Ca.: carcinoma

${ }^{*} \mathrm{p}<0.001,{ }^{* *} \mathrm{p}<0.02$

陽性率は $54.2 \%$ であった。偽陽性は急性肝炎，慢性肝 炎, 肝硬変, 肺炎, 肺線維症, 結核, 閉塞性肺疾患等 に認められ，殊に，炎症性疾患に偽陽性傾向を認めた。 肺癌患者全体の血清 TPA 陽性率は 63.3\%を示した。 組織型別にみると，いずれの組織型でる高い陽性率を 示し，有意差は認めなかった（Fig. 3).

健常者に打ける KA 32 の平均値＋1 SDである 44 $\mathrm{U} / \mathrm{m} l$ を cut off 值とすると, KA 32 陽性率は, 健常者 では $11.1 \%(2 / 18)$, 非腫瘍性呼吸器疾患患者では $31.3 \%(5 / 16)$ であった。

肺癌の組織型別 KA 32 陽性率は, 腺癌 29.4\% (5/ $17)$, 扁平上皮癌 $50 \%(4 / 8)$, 小細胞癌 $33.3 \%(2 / 6)$, 大細胞癌 50\%（2/4）で无った（Fig. 4).

健常者における KA 93 の平均値+2 SD（0.33）を cut off 值とすると, KA 93 陽性率は，健常者では $0 \%$ $(0 / 26)$, 非腫裳性呼吸器疾患患者 $0 \%(0 / 16)$ であ った.

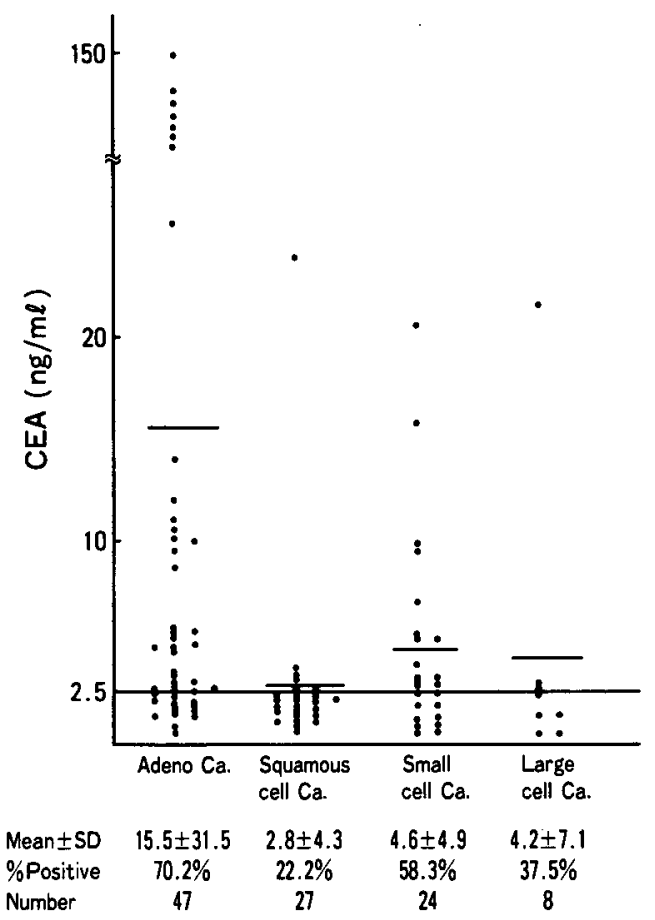

Fig. 2 Serum CEA levels in patients with car cinoma of the lung in relation to histological classification

CEA : carcinoembryonic antigen, Ca. : carcinoma

肺癌の組織型別 KA 93 陽性率は, 腺癌 $39.7 \%(23 /$ $58)$, 扁平上皮癌 $0 \%(0 / 32)$, 小細胞癌 $4.8 \%(1 / 21)$, 大細胞癌 $0 \%(0 / 9)$ であった（Fig. 5).

\section{2. 肺癌の病期と各種マーカー}

血清 NSE 陽性例は，I 期，II期においては認められ ず，III期，IV期において，それぞれ 25，44\%の陽性率 を示し，病変の進展をよく反映していた（Fig. 6).

血清 CEA 陽性率は，III期 $41.9 \%$, IV期 70.6\%を示 した. I 期 $0.7 \pm 0.1 \mathrm{ng} / \mathrm{m} l$, II 期 $5.3 \pm 10.8 \mathrm{ng} / \mathrm{m} l$, III期 $3.9 \pm 4.4 \mathrm{ng} / \mathrm{m} l$ を合わせた平均値とIV期 $14.2 \pm$ $30.3 \mathrm{ng} / \mathrm{m} l$ の平均值とでは, $\mathrm{t}$ 検定で $\mathrm{p}<0.05$ と有意 差を認めた (Fig. 7).

血清 TPA 陽性率は，I期 $50 \%$ ，II 期 60\%，III期 $58.5 \%, \mathrm{IV}$ 期 $70.5 \%$ を示し, 各々の病期の間では特に 有意差は認められず，I期，II期においても高い陽性 率を示した (Fig. 8).

KA 32 と病期との関保では，いずれの組織型におい てもIII期またはIV期の症例において高值を示す傾向が 


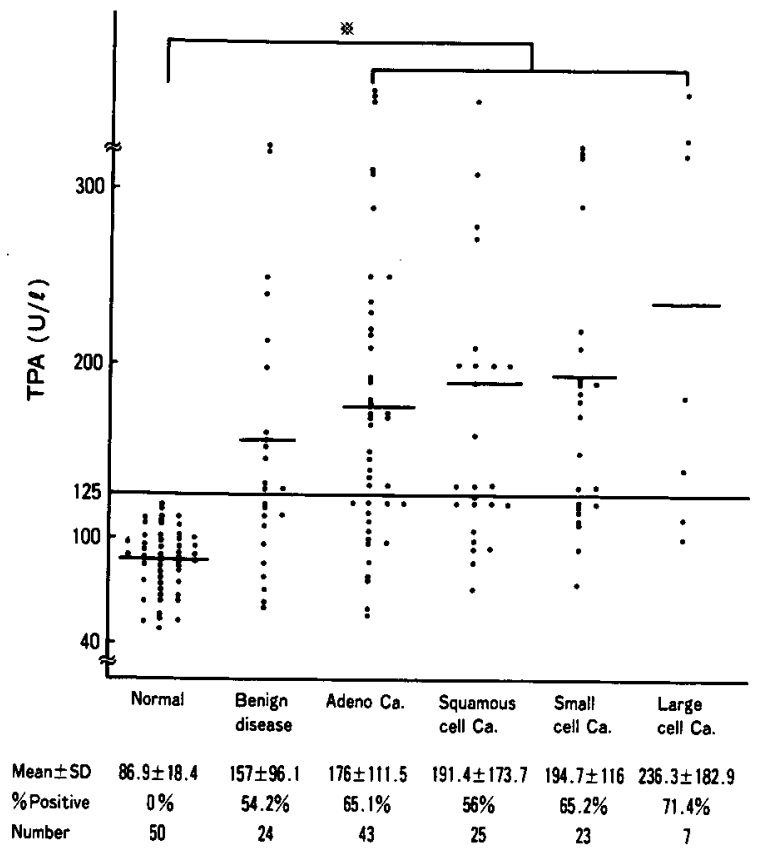

Fig. 3 Ranges of serum TPA values in controls and patients with benign disease or carcinoma of the lung

TPA : tissue polypeptide antigen, $\mathrm{Ca}$ : : car. cinoma

${ }^{*} \mathrm{p}<0.001$

認められた(Fig. 9). また，KA 32 と既存の腫瘍、一 カーである CEA，AFP との相関係数は，それぞれ $0.06 ， 0.05$ で相関は認めなかった。

KA 93 と病期との関係でも, 病期の進展とともに高 値を示す傾向が認められた（Fig. 10）.

\section{3. 小細胞癌患者の病期分類と血清 NSE}

血清 NSE 陽性率は，III期 $55.6 \%$, IV期 94.1\%で, $\chi^{2}$ 検定によって $\mathrm{p}<0.05$ と有意差が認められた。血清 NSE 平均値は, III期，IV期の間に有意差は認められな かったが，IV期の症例において高い傾向が認められた (Fig. 11).

\section{4. 小細胞癌患者の治療勃果と血清 NSE}

Fig. 12 に初回化学療法によって, partial response (PR) 以上の治療効果を示した有効例の経時的 NSE の変化を示す. 12 例全例において, 血清 NSE は 10 $\mathrm{ng} / \mathrm{m} l$ 以下の正常範围まで低下したが，再発によって 再び血清 NSE の増加が認められた。しかしながら，1 例に打いては脳転移栄の再発にもかかわらず，血清

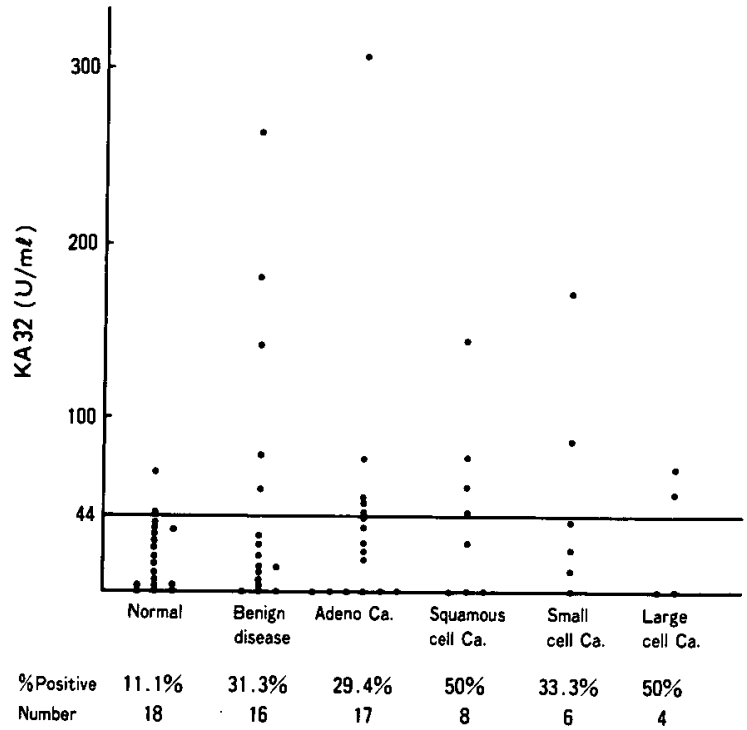

Fig. 4 Ranges of KA 32 by ELISA in sera from controls and patients with benign disease or carcinoma of the lung

KA 32 : serum antigen which recognized by monoclonal antibody, KM 32 which had been produced from the mouse immunized with human lung squamous cell carcinoma tissue.

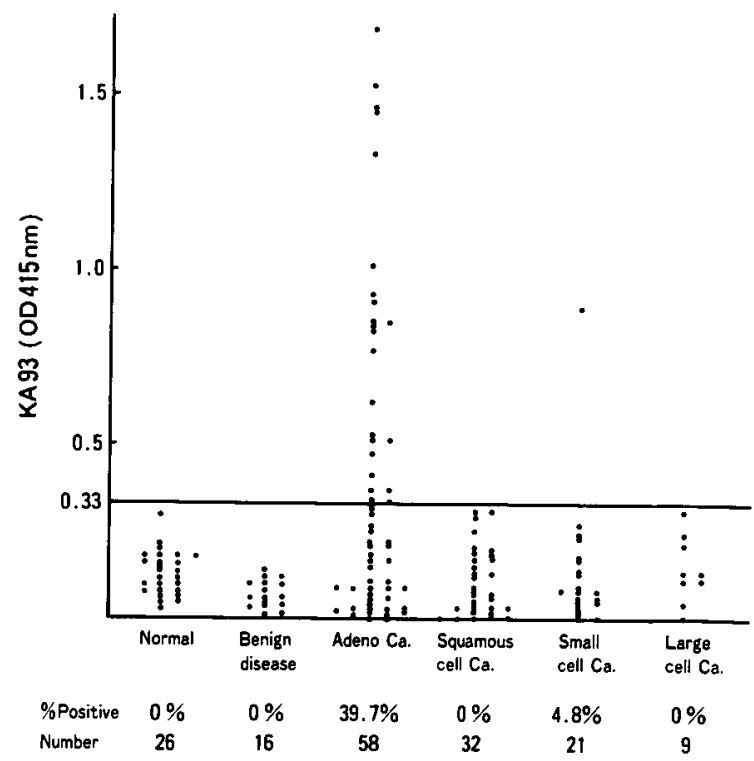

Fig. 5 Ranges of KA 93 by ELISA in sera from controls and patients with benign disease or carcinoma of the lung

KA 93: serum antigen which recognized by monoclonal antibody, KM 93 which had been produced from the mouse immunized with human lung adenocarcinoma tissue. 


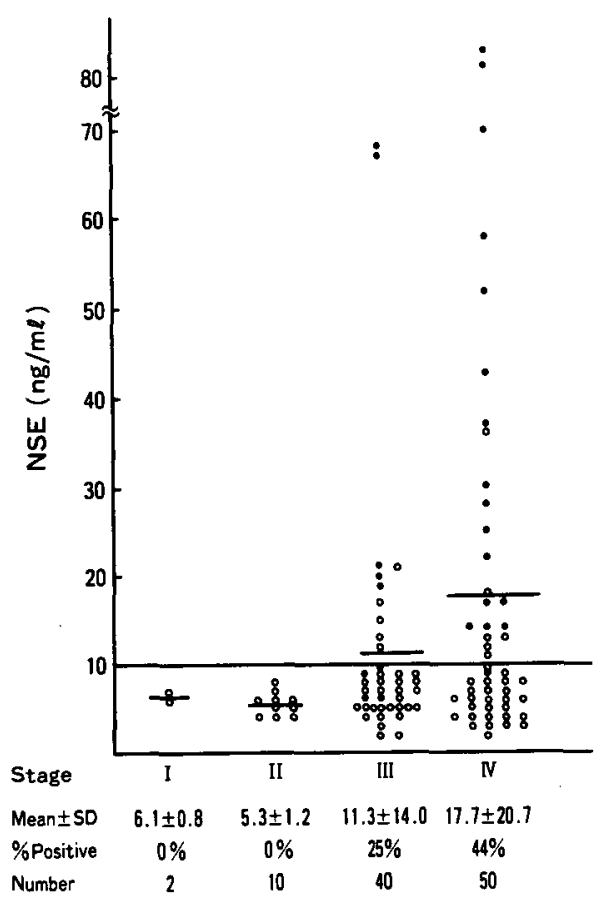

Fig. 6 Serum NSE levels in patients with carcinoma of the lung in relation to the stage of disease

: small cell carcinoma, $O$ : non small cell carcinoma

NSE の増加は認められなかった。

Fig. 13 に治療効果を示さなかった無効例をたは増 悪例における血清 NSEの变化を示寸。全例において, 血清 NSEは不变または増加を示していた。

\section{5. 小細胞癌患者の再発と血清 NSE}

経時的に血清 NSE を測定した症例の臨床経過を示 す. Fig. 14, 15 に示す症例は, いずれる臨床的に画像 診断によって再発が確認される $2 \sim 6$ 週間前に, 血清 NSEの上昇を認めた。な㧍，経過とともに血清 NSE を経時的に測定しえた 6 例のうち，この 2 例を含む 3 例は, 臨床的に再発を確認寸る前から血清 NSEの上 昇が認められたが，他の 3 例は，再発が明らかにされ た時点においても血清 NSEの上昇は認められなか った。

\section{6. 血清 NSE と CEA, TPA との相関関係}

Fig. 16 に血清 NSEとCEAを同時に測定した肺 癌患者 95 例の相関を示す. $r=-0.01$ で相関は認めら れなかった. Fig. 17 に血清 NSE と TPA を同時に測

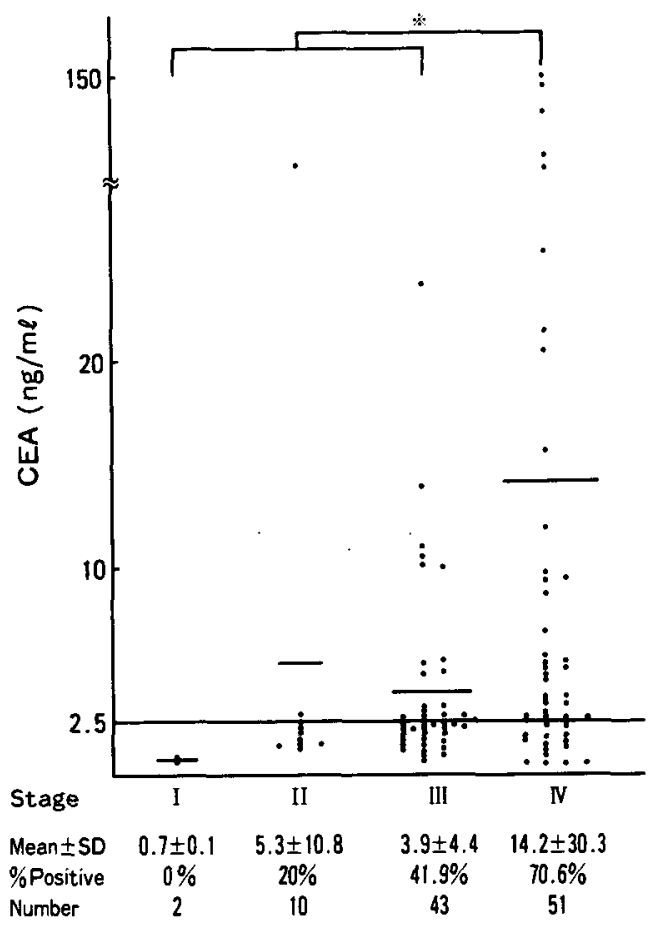

Fig. 7 Serum CEA levels in patients with carcinoma of the lung in relation to the stage of disease ${ }^{*} \mathrm{p}<0.05$

定した肺癌患者 90 例の相関を示す。 $r=0.17$ で相関は 認められなかった。

\section{考 察}

原発性肺癌における血清 NSE の上昇は，特に小細 胞癌に招いて著しく，その陽性率もこれまでの報 告 ${ }^{5-12)}$ では，64〜75\%といわれている. 今回の検討で は,小細胞癌の NSE 陽性率は $80.8 \%$ であり,これまで の報告より高い陽性率であった。非小細胞癌の血清 NSE 陽性率は, 8〜29\%と報告6,9 12) されており, 著者 の検討では $14.5 \%$ であった。組織型別検討では，腺癌 $11.4 \%$, 扁平上皮癌 $12.5 \%$, 大細胞癌 $37.5 \%$ で, 非小 細胞癌の中では，大細胞癌に括いて血清 NSE陽性率 が高い傾向であった（Fig. 1)，この成績は，有吉らの 報告 ${ }^{13)}$ とほぼ一致した。非小細胞癌における組織型別, 血清 NSE 陽性率は，発表者によってバラッキがみら れるが，その原因としては, 症例数, 対象とした肺癌 患者の病態の差, 測定法が enzyme immunoassay (EIA) か radioimmunoassay（RIA）かの相違，キッ トに使用されている抗原, 抗血清の特異性の違いなど 


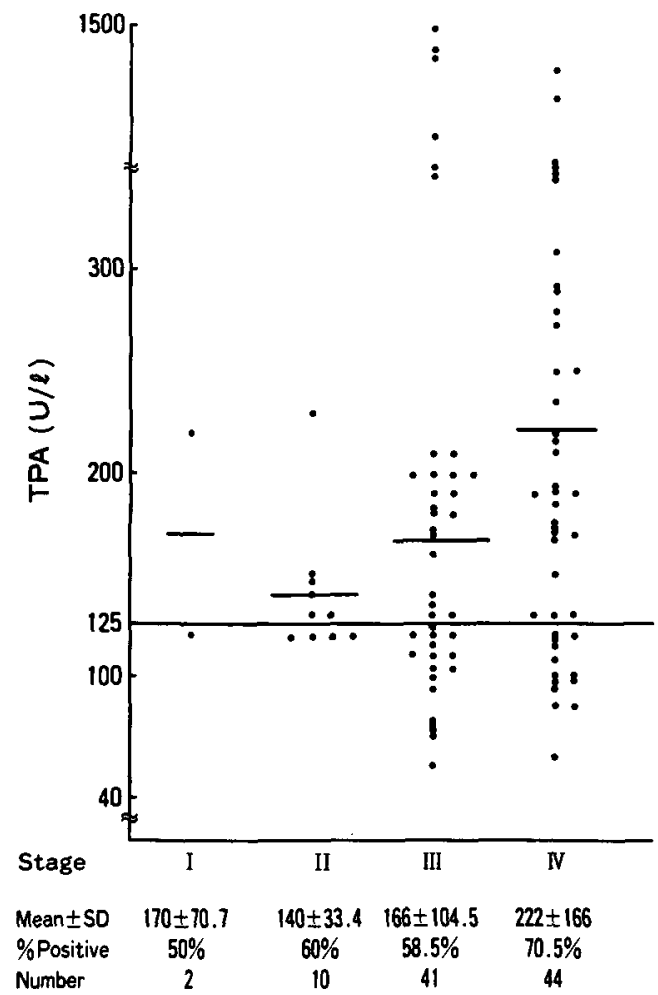

Fig. 8 Serum TPA levels in patients with carcinoma of the lung in relation to the stage of disease

によることが考学られる、いずれにしても，非小細胞 癌にも血清 NSE 陽性例が存在することは，小細胞癌 が神経内分泌細胞由来上考えられることより，肺癌の 組織発生を考える上で興味深いことである。

肺癌の病期と血清 NSEに関して，著者の検討では， I 期, II 期に陽性例はみられず, III期, IV 期の血清 NSE 陽性率は，それぞれ 25，44\%で病変の広がりをよく反 映していた(Fig. 6)。さらに, 腫瘳が一側胸郭と緃隔, 同側鎖骨上リンパ節に限局した limited disease (LD) と，腫煌がこの範囲を超えた extensive disease (ED) とに㧍ける血清 NSEの平均値は，LD例に比較して $\mathrm{ED}$ 例で有意に高いとする報告5,7,11,12)が多いが，著者 の検討でも，ED例に相当するIV期例の陽性率がIII期 例のそれに比較して高く，やはり病変の広がりとの間 に密接な相関が認められている。

血清 NSEの経時的測定は, 小細胞癌の治療効果の モニタリングに有用であると報告5 8)されている.著者 の検討でも, 初回化学療法前後に血清 NSE の測定を 行った 20 例のらち, complete response (CR) または

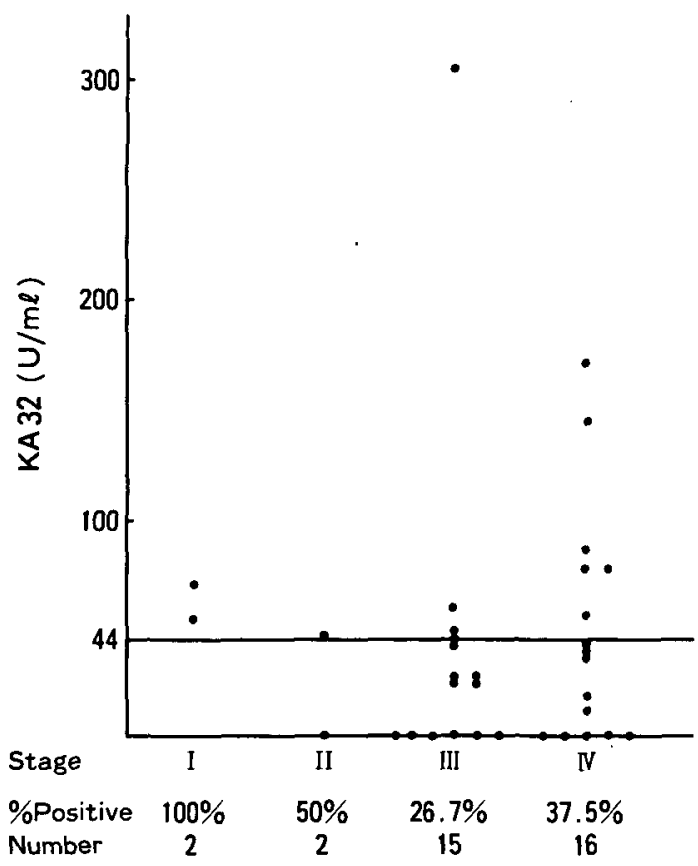

Fig. 9 Serum KA 32 levels in patients with carcinoma of the lung in relation to the stage of disease

partial response (PR) の治療効果を示した 12 例全例 において, 血清 NSEは $10 \mathrm{ng} / \mathrm{m} l$ 以下の正常值になで 低下した（Fig. 12）が，治療効果を示さなかった no change (NC) また progressive disease (PD) 例に 㧊いては，全例血清 NSEの低下を認めないか，上昇を 認めた（Fig. 13).

この成績から, 血清 NSEの变動は, 化学療法効果に 伴ら病態の推移を非常によく反映していることが示唆 された。

Johnson ら7は，臨床的に再発が認められる以前か ら頻回に血清 NSE を測定した 23 例に打いて，15例 (65\%)では，臨床的再発より2 12 週前に血清 NSE の上昇を認めたと報告している。著者の検討した症例 においても，臨床経過を追って血清 NSEの経時的測 定を行いえた小細胞癌 6 例の5ち 3 例において，臨床 的に画像診断で再発が確認される $2 \sim 6$ 週前に血清 NSE の上昇が認められた。化学療法, 放射線療法が有 効な治療法之される小細胞癌の臨床において, 再発, 増悪の早期発見は，再治療を早期に開始する5えで非 常に重要である。したがって，血清 NSEの経時的測定 は，再発，增悪の指標として臨床的に有用であること を示している。 


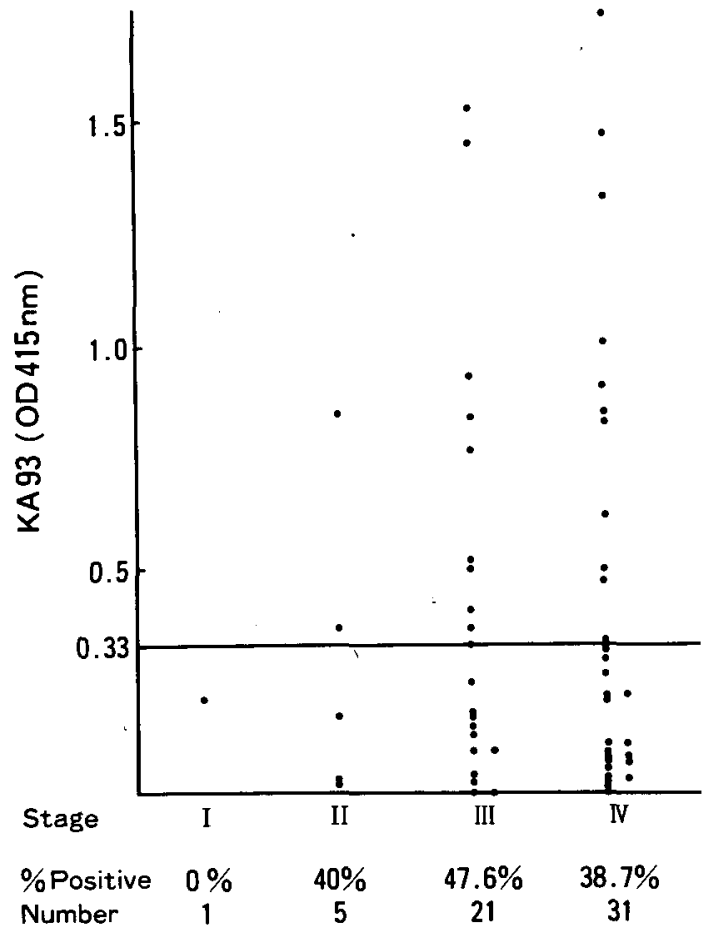

Fig. 10 Serum KA 93 levels in patients with carcinoma of the lung in relation to the stage of disease

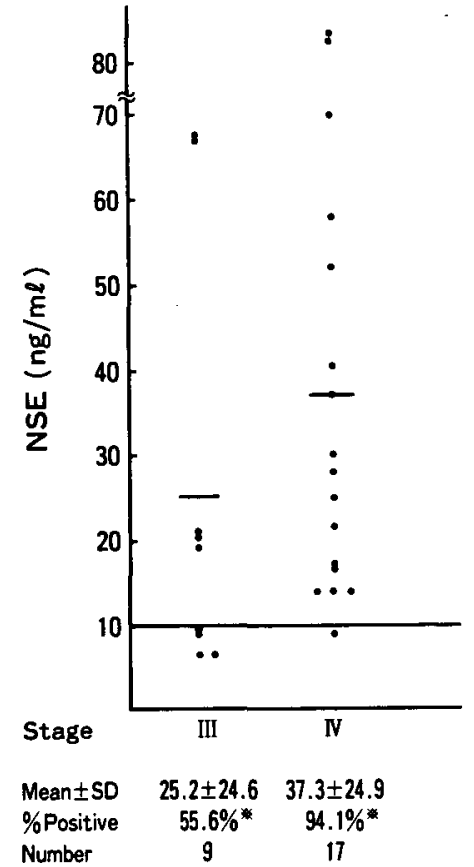

Fig. 11 Serum NSE levels in patients with SCLC in relation to the stage of disease SCLC : small cell lung carcinoma ${ }^{*} \mathrm{p}<0.05$

(Fig. 2).

宮本ら ${ }^{22)}$ は, 進行肺癌患者(病期III, IV)の血清 CEA について, 治療前の值を $2.5 \mathrm{ng} / \mathrm{m} l$ 以下, $2.6 \sim 5.0$ $\mathrm{ng} / \mathrm{m} l$ お。よび $5.1 \mathrm{ng} / \mathrm{m} l$ 以上とに分類し，それぞれを CEA 非産生型, 低産生型, 拉上び高産生型とし，CEA の推移を観察すると，低産生型は扁平上皮癌に多く， 死亡時なで $20 \mathrm{ng} / \mathrm{m} l$ 以上となる例は少ないという. 著者の成績を宮本らの方法で分析すると，CEA 陽性率 は, 腺澏 $42.6 \%$, 扁平上皮癌 $3.7 \%$, 小細胞癌 $33.3 \%$,

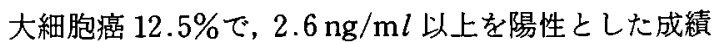
(Fig. 2) とほぼ同じ傾向を示した.

一方, Sun 5 23)性, 免疫組織化学的な手法を用いて険 索した結果，他の組織型に比較して，腺癌組織に高い 割合でCEA が存在することを認めており，このこと は，腺癌が高率に CEA を産生している証拠であると 報告している。

Shinkai ら ${ }^{24)}$ は, 血清 CEA が $20 \mathrm{ng} / \mathrm{m} l$ 以上を示す 症例は，腺癌患者の $43 \%$ にみられ，小細胞癌 $24 \%$, 扁 平上皮癌 $7 \%$ との間に有意差を認めたと報告してい る. 今回検討した症例でも血清 CEA が $20 \mathrm{ng} / \mathrm{m} l$ 以上 


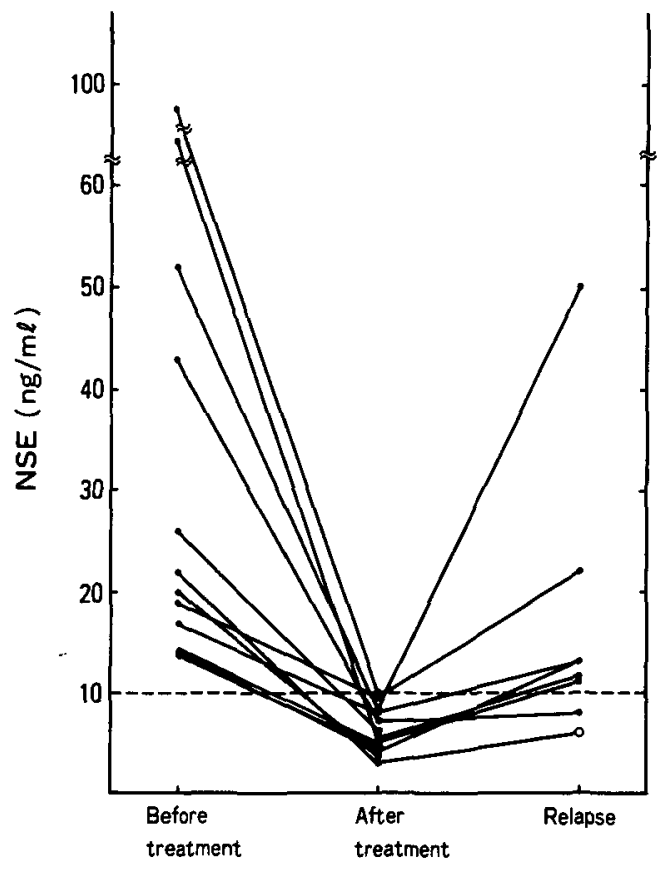

Fig. 12 Serum NSE levels in SCLC patients before treatment, initial clinical response, and at relapse from cytotoxic therapy

$O$ : no relapse

を示したのは，腺癌に多く，全症例の $80 \%$ は腺癌で, やはりSun らの報告を支持する結果が得られている。 臨床病期と血清 CEA との関連では，堂坂ら 25)は，I 期拈よびII期症例の陽性率（23.5，18.1\%）とIII期お

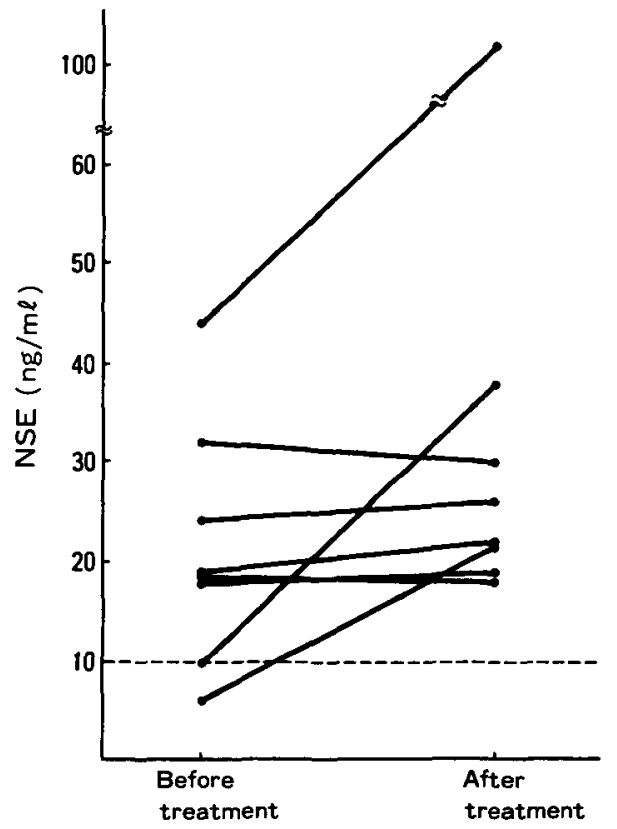

Fig. 13 Serum NSE levels in SCLC patients whom no responded to cytotoxic therapy

よびIV期症例の陽性率（48，68\%）との間に有意差を 認めたと報告しており，またDent $~^{26)}$ は， extensive disease と limited disease の間で，血清 CEA の平均 値に有意差があったと報告している，著者の検討した 症例においてもFig. 7 に示すごとく，I，II，III期と IV期の血清 CEA の平均值の間には $\mathrm{t}$ 検定で有意差を

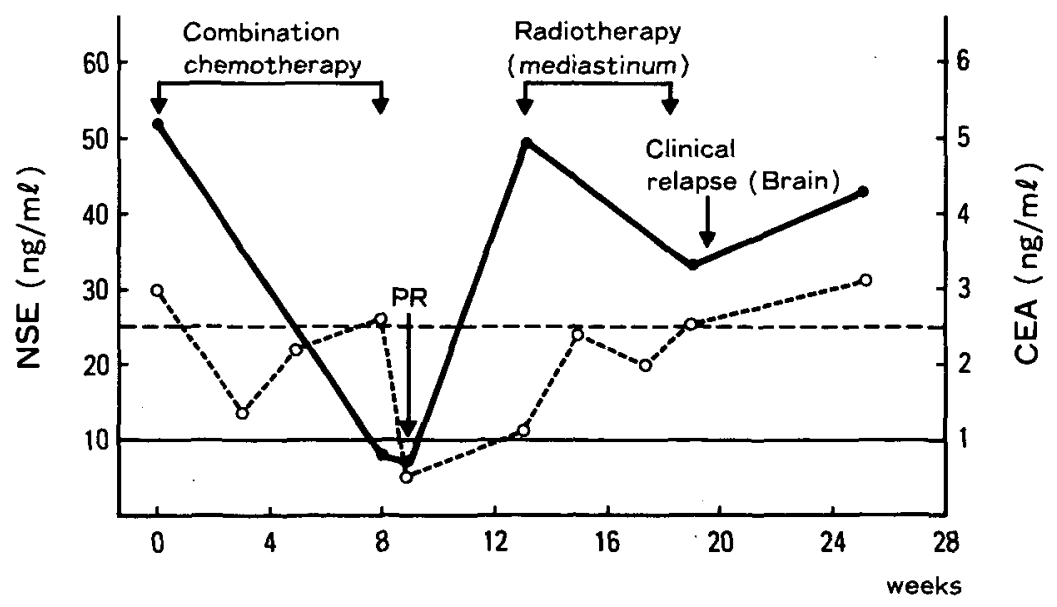

Fig. 14 Serial NSE and CEA levels in SCLC patient NSE level falls at initial clinical response and then begins to rise 6 weeks prior to relapse.

: NSE, O: CEA, PR: partial response 


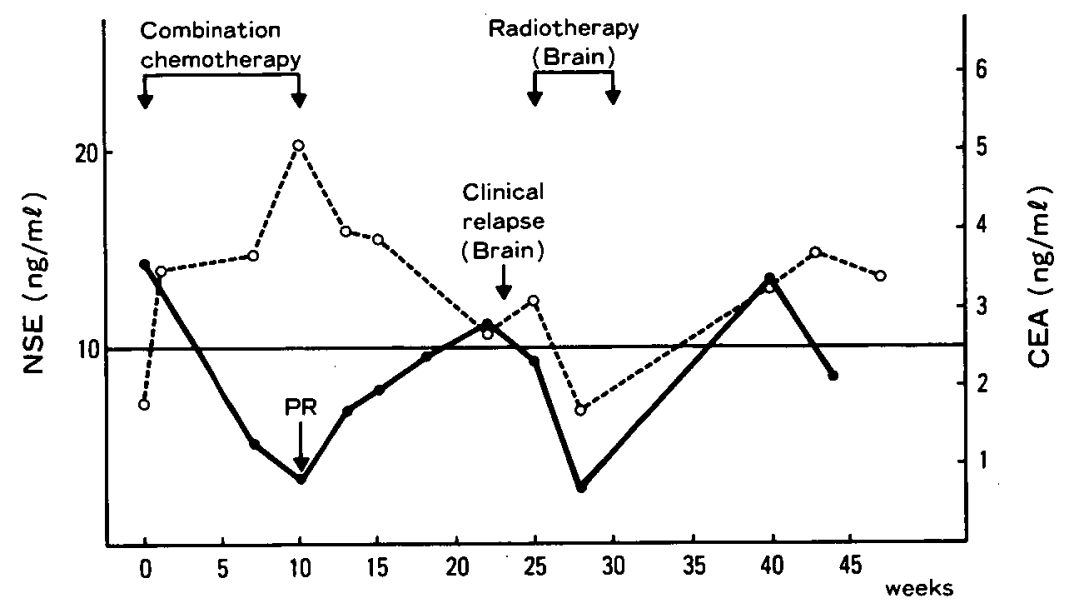

Fig. 15 Serial NSE and CEA levels in SCLC patient NSE level falls at initial clinical response and then begins to rise 1 week prior to relapse.

: NSE, O : CEA, PR : partial response

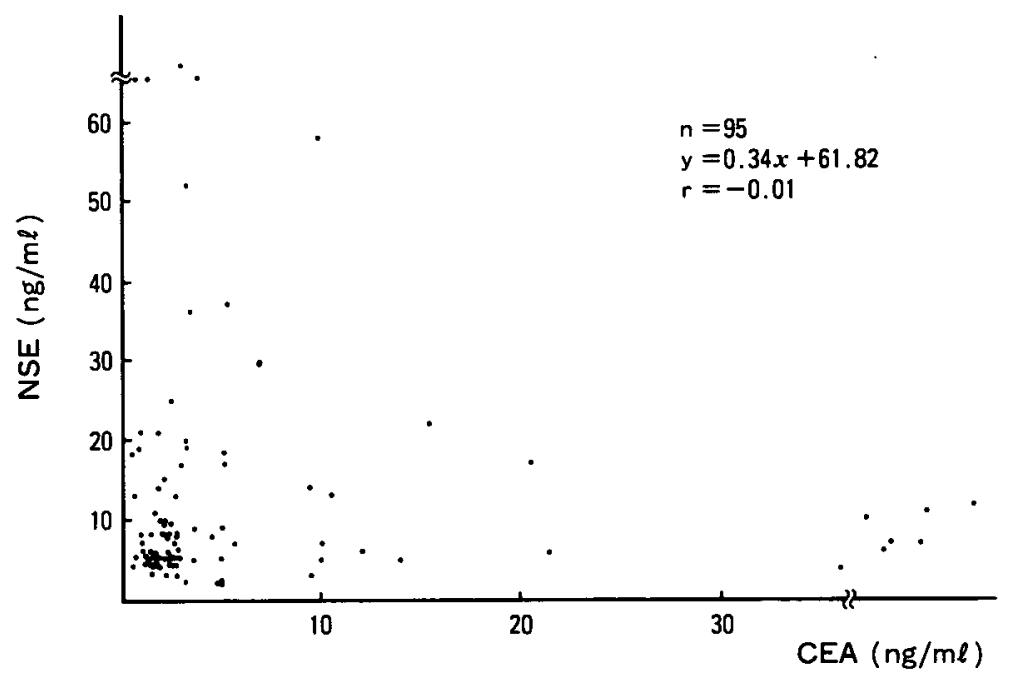

Fig. 16 Correlation between serum levels of NSE and CEA in carcinoma of the lung

認めている $(\mathrm{p}<0.05)$.

これらのことより, 血清 CEA む病変の進展を反映 するマーカーと考えられた。

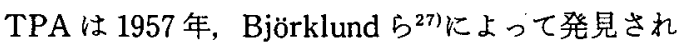
た分子量約 22,000 25,000の single chain polypeptide であり, 癌細胞の原形質膜や小胞体に多く存在す るといわれている，最近，睡湯マーカーとして，臨床 的意義が論議されている28).

肺癌に抢ける，血清 TPA 陽性率は，46.7 80\%と報 告29 36)されており, 著者の検討では, 血清 TPA 陽性率
は63.3\%で，ほぼ同様の結果であった。

組織型別での血清 TPA 陽性率は, 腺癌 $65.1 \%$, 扁 平上皮癌 $56 \%$, 小細胞癌 $65.2 \%$, 大細胞癌 $71.4 \%$ と, 各組織型とも高い陽性率を示し，各組織型間で有意差 は認めなかった（Fig. 3)。

村木ら ${ }^{36)}$ は, 肺癌の早期から高い血清 TPA 陽性率 を示したと報告しており，著者の病期別検討でも cut off 值を $125 \mathrm{U} / l$ とした場合，早期から高い陽性率を 示し，肺癌における早期発見のスクリーニングマー カーとして有用であることを示唆している。 


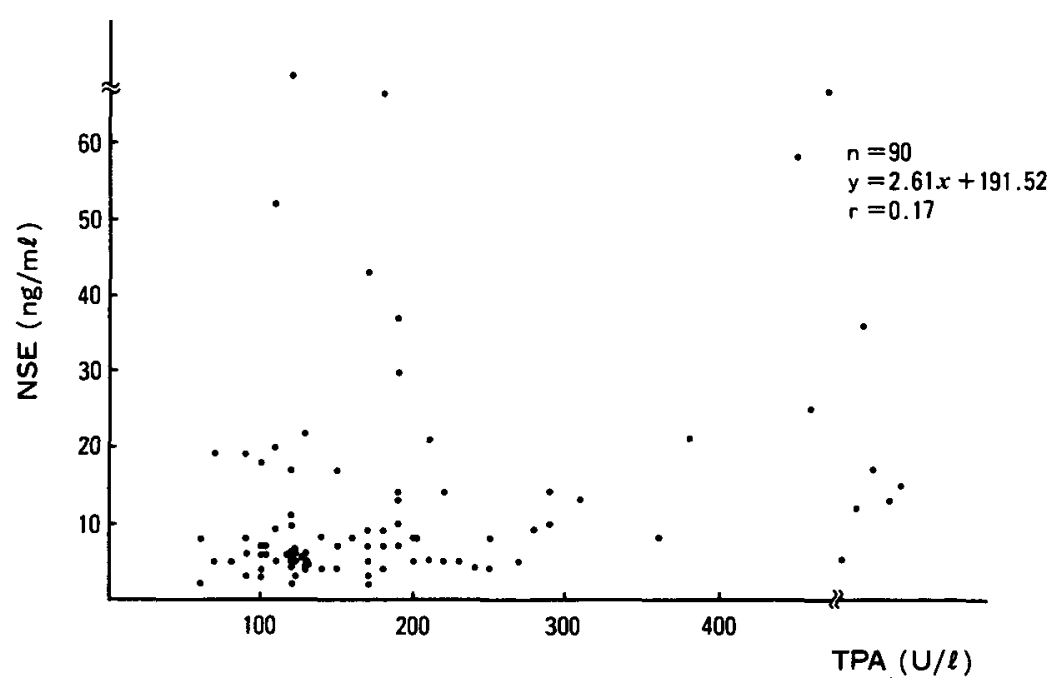

Fig. 17 Correlation between serum levels of NSE and TPA in carcinoma of the lung

一方, 血清 TPA 值は, 炎症性疾患でも高率に陽性を 示すことが知られて扣り，著者の非腫瘍性疾患患者に おける検討でも，血清 TPA 陽性率は $54.2 \%$ と偽陽性 が多いよらに思われた（Fig. 3).

桑原 ${ }^{33)}$ は, 资症性疾患の血清 TPA 值の平均値士2 $\mathrm{SD}$ の上限から, 得られた $200 \mathrm{U} / l$ を cut off 值とする ことが, 腫瘍マーカーとして妥当であると述べている。 しかし, 偽陽性例が多いとはいえ $200 \mathrm{U} / l$ を cut off 值 とすると，著者の成績では，I，II期症例の陽性率が 低下し，早期発見のスクリーニングとしての有用性が 低下するので, cut off 值の設定は今後の課題と思わ れる。

近年, 悪性腫埸診断の一つの方法として,モノクロー ナル抗体を用いて血清中の癌抗原を検出する試みがな されている。検出された抗原は，CA 19-9，CA 125， CA 50, Ca-1 シフル SSEA-1, DU-PAN-2, CSLEX 1 など多くの報告がある。これらのうちの多くは，癌細 胞表面の糖鎖抗原をモ,クローナル抗体が認識するた めに検出可能となった。

ヒト肺腺癌細胞膜成分に対するモノクローナル抗体 KM 93 は, cell binding ELISA で一部の胃癌, 白血病 細胞株等と反応し，また免疫組織化学的検討で, 肺気 管支上皮, 気管支腺, 膵管上皮, 腸管上皮, 永細管上 皮等の正常組織上も反応すると報告4されている。し かし, cut off 值の設定により肺腺癌に高い特異性を認 めた。

KM 93 によって認識される抗原 KA 93 は, CEA,
AFP, $\beta_{2}$ マイクログロブリン, CA 19-9, DU.PAN-2 と 異なり, 肺癌患者の胸水から分離されたものは, 分子 量 100 万以上の高分子として存在するシアル酸を含む 糖鎖抗原である ${ }^{4}$.

今回の成績から，KM 93 は肺腺癌に対する特異性が 高く, 健常者, 非腫瘍性呼吸器疾患患者血清で偽陽性 率が低く, 肺癌血清診断への応用上, 有用なマーカー であることが示唆された.

\section{結 論}

1）原発性肺癌患者全体に打ける血清 NSE, CEA, TPAの陽性率は，それぞれ31.4，52.8，63.3\%であ った.

2) 組織型別検討では, 血清 NSE 陽性率は小細胞癌 患者で $80.8 \%$ を示し，また平均值 $(32.7 \pm 25.4 \mathrm{ng} / \mathrm{m} l)$ も他の組織型に比較して有意に高值であった，血清 CEA 陽性率は腺癌患者で $70.2 \%$ をし，扁平上皮癌 患者の陽性率より有意に高かった。血清 TPA 陽性率 は，各組織型間で有意差を認めなかった。

3）病期との関連では，血清 NSE，CEA 陽性率は， IV期でそれぞれ 44，70.6\%を示し，病変の進行をよく 反映した。一方, 血清 TPA 陽性率は, 早期から高い傾 向を認めたが, 非腫湯性疾患患者でも54.2\%の陽性を 認め, 特異性という点で問題があった。

4）小細胞癌患者で高い陽性率を認めた血清 NSE の経時的測定は, 病変の進行, 治療効果, 再発, 增悪 の予知など治療経過モニタリングに有用と思われた。 
5）ヒト肺扁平上皮癌に対す，モノクローナル抗体 KM 32 によって検出される血清抗原 KA 32 は, 扁平 上皮癌患者で $50 \%$ の陽性率を認めたが，健常者，非腫 瘍性呼吸器疾患患者でも，それそれれ 11.1，31.3\%の陽 性率を示し，やや特異性に問題があった。

6) ヒト肺腺癌に対する, モノクローナル抗体 KM 93 によって険出される血清抗原 KA 93 は, 腺癌 患者で $39.7 \%$ の陽性率を認め, 健常者, 非腫县性呼吸 器疾患患者では陽性者を認めず，腺癌患者において比 較的特異性が高かった。

稿を終えるにあたり，協和発醭東京研究所の好田蛲博士に深謝 致します。また, 直接御指導, 御校閲睗りました, 青山昭徳講師, 矢野佩助教授，ならびに教室員各位に感謝申し上げます。

なお，本論文の要旨は，第 26 回日本肺癌学会総会（1985 年 10 月)ならびに第 44 回日本癌学会総会 (1985年 10 月)において発 表した。

\section{文 献}

1) Tapia, F.J., Polak, J.M., Barbosa, A.J.A., Bloom, S.R., Marangos, P.J., Dermody, C. and Pearse, A.G.E. : Neuron-specific enolase is produced by neuroendocrine tumours. Lancet, I(8224), 808 811, 1981.

2) Prinz, R.A. and Marangos, P.J.: Use of neuron specific enolase as a serum marker for neuroendocrine neoplasms. Surgery, 92, 887 889, 1982.

3）花井陳雄，好田㹂：抗ヒト肺癌モノクローナル抗体.（第 1 報）ヒト正常肺トレランスマウスを用いるヒト肺扁平上皮 癌に対するモノクローナル抗体の作製。第44回日本癌学会総 会記事, p. 130, 1985.

4）設楽研也，花井陳雄，好田匴：抗ヒ卜肺癌モノクローナル抗 体. (第 2 報) ヒト正常肺トレランスマウスを用いる肺腺癌 に対するモノクローナル抗体の作慜. 第44回日本癌学会絵会 記事, p. 130, 1985.

5) Canney, D.N., Marangos, P.J., Ihde, D.C., Bunn, P.A., Jr., Cohen, M.H., Minna, J.D. and Gazdar, A.F.: Serum neuron-specific enolase ; A marker for disease extent and response to therapy of small-cell lung cancer. Lancet, 1 (8272), 583 585, 1982.

6) Ariyoshi, Y., Kato, K., Ishiguro, Y., Ota, K., Sato, T. and Suchi, T.: Evaluation of serum neuron specific enolase as a tumor marker for carcinoma of the lung. Gann, 74, 219 225, 1983.

7) Johnson, D.H., Marangos, P.J., Forbes, J.T., Hainsworth, J.D., Welth, R.V., Hande, K.R. and Greco, F.A.: Potential utility of serum neuron specific enolase levels in small cell carcinoma of the lung. Cancer Res., 44, $5409 \sim 5414,1984$.

8）有吉寛：肺癌の新しい腫瘍マーカー；Neuron specific enolase の意義. 癌の臨, 30,569 573, 1984 .

9）藤沢武彦, 山口豊, 佐々木一義, 深沢敏男, 本郷弘昭, 小川 利隆, 木村秀樹：肺癌における血清 neuron specific enolase の腫瘍マーカーとしての意義。癌と化療, 12, 139 143, 1985.

10）增岡忠道, 松枝由美, 大川日出夫, 渡辺古志朗, 三本重治 : 原発性肺癌における neuron specific enolase (NSE) の測定
について. 医と薬学, 13, 573 577, 1985.

11) Akoun, G.M., Scarna, H.M., Milleron, B.J., Benichou, M. P. and Herman, D.P.: Serum neuron-specific enolase ; A marker for disease extent and response to therapy for small cell lung cancer. Chest, 87, 39 43, 1985.

12) Esscher, T., Steinholtz, L., Bergh, J., Nöu, E., Nilsson, K. and Påhlman, S.: Neuron specific enolase; A useful diagnostic serum marker for small cell carcinoma of the lung. Thorax, 40, 85 90, 1985.

13）有吉寛, 加藤兼房, 石黑土雄, 太田和男, 佐藤秩子, 須知泰 山: Neuron specific enolase (NSE). 癌之化療, 10, 1744 1753, 1984.

14) Gold, P. and Freedman, S.O.: Demonstration of tumor specific antigen in human colonic carcinoma by im. munological tolerances and absorption techniques. J. Exp. Med., 121, 439 471, 1965.

15) Lo Gerfo, P., Krupey, J. and Hansen, H.J.: Demonstration of an antigen common to several varieties of neoplasia. N. Engl. J. Med., 285, 138, 1971.

16) Gropp, C., Hanemann, K. and Lehmann, F.G.: Carcinoembryonic antigen and ferritin in patients with lung cancer before and during therapy. Cancer, 42, 2802 2808, 1978.

17) Concannon, J.P., Dalbow, M.H., Liehler, G.A., Blake, K. E., Werl, C.S. and Cooper, J.W.: The carcinoembryonic antigen assay in bronchogenic carcinoma. Cancer, 34, 184 - 192, 1974.

18) Vincent, R.C., Chu, T.M., Fergen, T.B. and Ostrander, M. : Carcinoembryonic antigen in 228 patients with carcinoma of the lung. Cancer, 36, 2069 2076, 1975.

19）松原義人，池田貞雄，今村正之：肺癌患者におけるCarcinoembryonic antigen (CEA) 值の测定. 日胸臨, 35, 587 591, 1976.

20）井草秀樹：肺癌における CEA および PHA 皮唐反心の臨床 的検討. 日胸疾患会誌，16，765 772，1978。

21）白日高歩：肺癌患者の血清 CEA 值の測定ならびにその臨床 的意義. 日胸外会誌，27，1295 1299，1979.

22）宮本宏，井上勝一，村尾誠，橋本正人：肺癌患者に招ける血 清中の Carcinoembryonic antigen (CEA) と免疫抑制酸性 蛋白(IAP) 测定の意義について. 肺癌, 21, 553 -564, 1981.

23) Sun, N.C.J., Edgington, T.D., Carpentier, C.L., Mcafee, W., Terry, R. and Bateman, J.: Immunohistochemical localization of carcinoembryonic antigen (CEA), CEA-S, and nonspecific cross-reacting antigen (NCA) in carcinoma of lung. Cancer, 52, 1632 1641, 1983.

24) Shinkai, T., Saijo, N., Tominaga, K., Eguchi, K., Shimizu, E., Sasaki, Y., Fujita, J., Futami, H., Ohkura, H. and Suemasu, K.: Serial plasma carcinoembryonic antigen measurement for monitoring patients with advanced lung cancer during chemotherapy. Cancer, 57, 1318 - 1323, 1986.

25）堂坂弘俊, 宮本宏, 井上勝一, 大崎饒, 村尾誠：肺小細胞激 患者に打ける血清中の carcinoembryonic antigen (CEA) 测定の意義. 癌の臨, 28, 1119 1125, 1982.

26) Dent, P.B., Mcculoch, P.B., Wesley-James, O., Maclaren, R., Muirhead, W. and Dunnet, C.W.: Measurement of carcinoembryonic antigen in patients with bronchogenic carcinoma. Cancer, 42, 1484 1491, 1978.

27) Björklund, B. and Björklund, V.: Antigenicity of pooled 
human malignant and normal tissues by cyto. immunological technique; Presence of an insoluble, heat-labile tumor antigen. Int. Arch. Allergy Appl. Immunol., 10, 153 184, 1957.

28) Björklund, B.: On the nature and clinical use of tissue polypeptide antigen (TPA). Tumor Diagnostik., 1, 9 20, 1980.

29) Björklund, B.: Tissue polypeptide antigen (TPA); Biology, biochemistry, improved assay methodology, clinical significance in cancer and other conditions, and future outlook. Antibiot. Chemother., 22, 16 31, 1978.

30) Menendez-Botet, C.J., Oettgen, H.F., Pinsky, C.M. and Schwartz, M.K.: A preliminary evaluation of tissue polypeptide antigen in serum or urine (or both) of patients with cancer or benign neoplasms. Clin. Chem., 24, 868 872, 1978.

31) Luthgens, M. and Schlegel, G.: Combined use of carcinoembryonic antigen in oncologic therapy and surveillance. Cancer Detect. Prev., 6, 51 59, 1983.
32) 桜井武雄, 横井秀樹, 岡田一男, 岡田浪速, 鳥住和民, 太田 久雄, 得律修一, 岡田多加志: 肺痁, 乳癌症例における新し い腫湟マーカーTPAの意義. 医々薬学 10,941 948, 1983.

33）桑原正善, 松原義人, 二宫和子, 池修, 安田雄司, 中田徹, 青木稔, 宮本好博, 畠中陸郎, 船津武志, 池田貞雄 : 肺癌患 者に打ける血清 TPA，最新医，39，627～628，1984。

34）木谷佰, 米島学, 澤武紀雄, 北川浩文, 竹森康弘, 登谷大修, 小林健一，服部信：各種消化器癌におりる血清 Tissue polypeptide antigen(TPA)の検討. 最新医, 39, 633 - 634, 1984 .

35）長田篤雄, 田中豊秋, 山羽義貴, 届藤進：Tissue polypeptide antigen (TPA) の radioimmunoassay kit の基磷的検討々 臨床意義について。核医, 21，177～190，1984.

36）村木憲子, 河内文雄, 長尾啓一, 婇辺昌平, 山岸文雄：肺癌, 肺結核扣よび僈性閉塞性肺疾患における血清中TPA 值の 検討. 日胸臨，44, 990 - 995, 1985.

（受付：1988年10月19日） 